\title{
Mangrove Ecosystem, Seagrass, Coral Reef: its Role in Self-Purification and Carrying Capacity in Coastal Areas
}

\author{
Hasim $^{1}$ \\ *Corresponding Email: hasim@ung.ac.id \\ ${ }^{1}$ Postgraduate Marine Science Study Program, State University of Gorontalo, Indonesia
}

\begin{abstract}
The coast is an area that has very high activity. It is estimated that $60 \%$ of the world's population lives in coastal areas. Various types of pollution enter this area. Halogenated hydrocarbons, pesticides, marine biotoxins, synthetic fertilizers, livestock and fishery waste, heavy metals, hot water discharges and radioactive substances. Coastal areas are natural ecosystems built by unique ecosystems including mangrove forests, seagrass beds and coral reefs. The three ecosystems interact dynamically and are interdependent. One of the characteristics of natural ecosystems is the ability to self-purify so that their carrying capacity is optimal. The coastal self-purification capacity is built by the synergy between the physical, chemical and biological components as well as their hydrological-morphological components. The self-purification mechanism includes filtration, transformation, degradation and decomposition. Self-purification is the ability of coastal ecosystems to accept a certain amount of waste in a complex natural process and before there is an indication of a decrease in its intended function. The implementation of self-purification effectively will support the optimization of carrying capacity, namely the ability of the ecosystem to support the life of the population. There are three factors related to carrying capacity, namely the availability of natural resources, population and consumption levels.
\end{abstract}

Keywords: Coastal Areas, Mangroves, Seagrass Beds, Coral Reefs, Self-Purification and Carrying Capacity

Received: March 1, 2021

Received in Revised: March 20, 2021

Accepted: April 7, 2021

\section{Introduction}

The coast is a relatively shallow marine area and has a very high primary productivity level compared to the deep-sea area. Coastal areas are also a contributor to $60 \%$ of productivity in the ocean. This condition is supported by the richness of ecosystems in coastal areas such as the presence of mangroves, coral reefs and seagrass beds which serve as feeding grounds and spawning grounds for several types of aquatic fauna (Bengen, 2002). Besides that, coastal areas contain a wealth of natural resources that cannot be renewed, such as oil, gas and minerals as well as environmental services (Dahuri et al., 2013). The large potential of coastal natural resources encourages various economic activities in this area. The growth of development in coastal areas shows an increasing activity. It is estimated that 60 percent of the world's important cities are located in coastal areas and \pm 60 percent of the world's population, are in coastal areas. Increased economic activity and high coastal population density have the potential to produce large amounts of waste, domestic waste and industrial waste. These wastes and wastes, especially in developing countries, are directly disposed of in the environment. Then carried by the flow of river water into the coastal ecosystem. 
Coastal areas have a high diversity of natural resources. So many trustees are active in this area with different interests. The implication is that the use of natural resources in coastal areas has the potential to get rid of each other. If this condition continues, it has the potential to accelerate environmental degradation in coastal areas.

The experience of managing coastal natural resources so far has shown an extractive picture. Be delivered Bodin \& Crona (2008) the weak collective work of coastal communities in environmental management and extractive natural resource utilization activities have caused ecological damage. As a result, massive damage to coastal natural resources has occurred in various parts of the world. One indication of the degradation of coastal areas is the entry of various chemical compounds and sedimentation in the coastal water system. If the presence of various chemical compounds and solids are in a certain amount, it will have an impact on changing the ecological function of coastal water ecosystems.

Coastal areas as open natural ecosystems have the ability to self-purify or self-purify. The selfpurification process as a natural law of an ecosystem has the ability to neutralize chemical compounds through a complex process. Several studies on self-purification in nature have been carried out, including: Otsuka et al., (2006) about self-purification efficiency, (Kohata et al., 2003; Ostroumov, 2004) about self-purification in aquatic ecosystems. Boaden (1996) stated that the many studies related to the coast are not only due to its high biodiversity but also that this area has important economic and aesthetic values for humans. The implication is that the coast becomes the most dense economic space with various activities.

This paper aims to (1) review the concept of the coast and its typical ecosystem, (2) review the sources and types of pollution in coastal areas, and (3) synthesize self-purification and carrying capacity in coastal areas.

\section{Coastal Conception and Its Ecosystem Characteristics}

\section{Coastal Conception}

Several literatures provide coastal concepts, namely; (1) areas that are still affected by the two regimes are land phenomena such as sedimentation and river flow with ocean phenomena such as tides, waves, wind and intrusion; (2) the confluence area which is influenced by the characteristics of the sea and land while the actual coastal boundary does not exist; is an interfacial area where land, atmosphere and oceans interact in a delicate balance due to natural and human influences (Beatly et al., 2002; Bengen, 2002; Boaden, 1996).

The concept above describes the characteristics of a very dynamic coastal area with a varied ecosystem. Besides having great potential, the coastal environment is an area that is vulnerable to development activities. The high vulnerability of coastal areas is due to the dynamic interaction of the two forming regimes. This is in line with (French, 2004) which states that coastal areas and oceans are complex systems; in which various processes interact: natural (eg hydrology and geomorphology), social, cultural, welfare, and governance.

Another view shared by (Turner et al., 1998) that from environmental and socio-economic aspects, coastal areas provide three economic values, namely (1) direct use values, for example the value of fishery resources and the value of oil or gas resources; (2) indirect use values such as wave restraint and aberration for coral reefs and mangrove forests; (3) useless values such as existence value and bequest value. Some of these views illustrate that socio-economic conditions are one of 
the factors that determine the sustainability of coastal ecosystems. This means that the higher the activity in the coastal area, the higher the pressure on this ecosystem. If coastal management ignores its carrying capacity, the ecological function of the coast will be degraded.

\section{Coastal Area Ecosystem}

Huang (2010) explained that the coast is an area where the interaction between land and sea takes place intensively. Dahuri et al., (2013) states that in a coastal area there are one or more environmental systems (ecosystems) and natural resources. There are natural and artificial coastal ecosystems. Natural ecosystems such as mangrove ecosystems, seagrass ecosystems and coral reef ecosystems while artificial ecosystems such as islands, tidal rice fields and ponds. Bengen (2002) provides an explanation of these typical ecosystems and their interdependent interactions, which are briefly described below.

\section{Mangrove Ecosystem}

Mangroves or mangrove forests are wetland ecosystems in tidal areas. The word mangrove comes from the Portuguese mangue which means "tree" and the English grove which is used for trees and shrubs found in shallow water, sandy or muddy areas. This mangrove forest has a high tolerance for salinity or is called euryhaline. Mangrove forests have unequal zoning and associations between species that are influenced by the dynamics of their physical environment. For example, Rhizophora (red mangrove) is in a zoning that is directly opposite the outermost tide, while Avicennia is in a zoning towards the land. Generally, mangrove vegetation lives in a coastal physical environment with few waves and sediments. Therefore, the distribution of mangrove forests is determined by factors such as; water and air temperature, sedimentation, waves, chemical compounds, and tides (Quisthoudt et al., 2012; Sheppard et al., 2018).

Mangrove ecosystems are characterized by high primary productivity (the ability to produce carbohydrates/food sources through photosynthesis). Many scientific studies show that mangroves have an important role in supporting the quality and sustainability of life in coastal areas as well as maintaining fishery resources sumber. Polidoro et al., (2010) stated that the rate of loss of mangrove forests has increased sharply so that it is estimated that it will not only have an impact on the rapid loss of biodiversity and the threat of ecological functions. The subsequent implication is that it has a negative impact on the livelihoods of humans who are dependent on mangrove forests.

The functions and benefits of mangrove forests are related to the physical typology of the landscape. For example, in the estuary area, in the coastal area, in the island area and in the delta area. Some of the functions and benefits of mangrove forests are as follows: (Kawaroe et al., 2001; Lacerda, 2002; Twilley et al., 1992).

Plant provider; Mangrove forests have a very high diversity of natural plants. These plants are a source of energy because they have direct benefits for life such as food, drinks, medicines, shell charcoal, and food. Even the Nipa tree has traditionally been used as a roof for a long time. However, certain species such as Rhizophora samoensis, Avicenna bicolor, Mora oleifera and Tabebuia palustris are threatened with extinction (Polidoro et al., 2010).

Providers of fishery and non-fish resources; Mangrove forests naturally have a wealth of fishery and non-fish resources. like shrimp and crab. These resources, in addition to having high nutritional value, also have important economic value. Mangroves are places where several types 
of fish, shrimp and crabs are economically important. Martosubroto \& Naamin (1977) stated there is a positive linear relationship between the area of mangrove forests and shrimp production.

Protection from natural disasters (hurricanes and Tsunamis); mangrove forest vegetation protects the coastline from abrasion and intrusion. Besides that, the mangrove forest becomes a protector during a tsunami or storm so that the damage that occurs can be minimized.

Nutrient storage, filter and recycler; The material cycle process occurs in a complex manner in mangrove forests so that it is very rich in nutrients. This condition is a factor in the mangrove ecosystem having a high level of productivity. Some biota make mangroves as habitats because of the abundant availability of food. In addition, mangrove roots become a trap for sediment particles brought from land flows. These sediment particles often contain nutrients and toxic compounds.

Carbon sequestration and storage; carbon absorption by mangrove vegetation through a complex process of photosynthesis. Thus, mangrove forests can function as mitigation of climate change triggered by carbon emissions into the atmosphere.

\section{Seagrass Field}

Seagrass is a flowering plant (angiospermae) that lives in coastal waters, one-bladed, has fruit, flowers and leaves with the shape of rhizome roots. according to (Larkum et al., 2006) Ascherson (1871) was the first researcher to include the term seagrass in the scientific literature and create a biogeographical map of the world seagrass. Based on this information, it is known that almost all coastal waters in the world are found with seagrass plants. For example along the tropical coast namely Thalassia, Halophila, Syringodium, Halodule, Cymodocea, Thalassodendron, and Enhalus. While several types of seagrass are found on sub-tropical beaches such as Zostera, Phyllospadix, Heterozostera, Posidonia, and Amphibolis.

Seagrasses can grow on almost any substrate on the coast. Seagrass habitats are marine waters with a slightly sandy substrate, including in coral reef areas. Ecologically, seagrass habitat is very much determined by the presence of sunlight for the process of photosynthesis. Then through the process of photosynthesis, simple inorganic chemical compounds become complex compounds containing high energy. The sustainability of life in the sea is largely determined by the ecosystem that is able to convert solar energy through photosynthesis. Therefore, seagrass ecosystems have a major contribution to the productivity of coastal areas in particular and the oceans (Boaden, 1996).

Seagrass is a coastal ecosystem whose existence is strongly influenced by anthropogenic activity. Submitted by (Allgeier et al., 2018) that the anthropogenic activity of industry and agriculture has supplied phospat and nitrate compounds for the survival and growth of seagrass. according to (Sheppard et al., 2018) generally seagrasses are found in atoll lagoons, behind barrier reefs, or on reef plains protected from edge coral reefs. The interaction between coral reefs and seagrass is very important in supporting biota life. These interactions also make up this region's very high productivity.

Larkum et al., (2006) states related to the association of seagrass vegetation with various faunal organisms that are demersal, benthic and pelagic. The diversity and abundance of fauna associated with seagrass is higher than in areas without seagrass. It was reported that the density of shrimp, sea urchin (Echinoidea), Mollusca, fish and crustaceans was higher in seagrass beds than in substrates without seagrass beds. It is also important that the fauna is a commodity with very high economic value. 
Liu et al., (2015); Nagelkerken et al., (2001); Randall (1965) mention the functions and benefits of seagrass ecosystems, among others: (1) Sediment traps carried by the movement of streams from rivers and the movement of coastal water. The trapped sediment carries macro and micro elements so that it becomes a nutrient for seagrass growth; (2) Water purifiers containing solids are suspended through leaf traps and their rhizomes. The solids are suspended by the exposed seagrass vegetation so that the solids fall to the base forming a consolidated substrate; (3) a good breeding spot for invertebrates and fish juvenils such as ocyurus chrysurus, scarus iserti, haemulon parra, haemulon sciurus, Lutjanus apodus and Lutjanus griseus. Because the food available is very abundant.

Food sources especially for herbivorous organisms. Besides, seagrass provides litter that is utilized by detritivore fauna. Reported by Randall, (1965) of the 59 types of herbivorous fish there are about 30 types of seagrass-eating fish. Besides the type of fish found also other types of biota fauna such as crustaceans, reptiles and mammals whose food source is seagrass. habitat for fauna whose life attaches to the leaves, rhizomes and among its headings. Such as Gastropods, Echinoderphate, crustaceans and some types of fish (Hutomo \& Azkab, 1987). Includes habitat for fish that make seagrass as a food source.

\section{Coral Reefs}

One of the most important ecosystems in coastal areas is coral reefs. Odum \& Odum (1955); Sheppard et al., (2018) states that coral reefs are iconic ecosystems of tropical seas that have a highly productive ecological wealth and are biologically highly biodiversity ecosystems in the world. This ecosystem provides many natural resources and environmental services of high economic value. For example marine food, marine tourism, coastal protection, aesthetics and cultural benefits (Moberg \& Folke, 1999). About 100 countries have coral reefs. Coral reefs provide an important source of protein for their communities. according to (Jennings \& Polunin, 1996) The area of coral reefs $1 \mathrm{~km}^{2}$ can support the protein needs of 300 inhabitants if no other source of protein is available.

In general coral reefs have habitats in shallow tropical ocean waters. However, coral reefs that live at a depth of more than $50 \mathrm{~m}$ are also found in cold waters. For example Stylasteridae, Scleractinia, Zoonthidae, Antiphataria are some types of coral found in cold sea waters (Sheppard et al., 2018). Coral reefs related to its ability to produce lime are divided into two types. Coral reefs capable of forming limestone buildings are called hermatypiccorals. While coral reefs that are not able to form limestone buildings are classified as ahermatypic coral. Hermatypic corals are associated with zooxanthellae (a type of algae) capable of photosynthesis. A byproduct of the symbiosis are deposits of calcium carbonate that make up distinctive structures and buildings. This type of coral is a limiting factor because the main requirement in the process of photosynthesis is the presence of sunlight (Supriharyono, 2000).

Based on geomorphology coral reefs are distinguished in three types. Fringing reefsare coral reefs located along the shore. Barrier reefs arecoral reefs that are located far from the coast and separated bylagoons. Ring coral reefs (atolls)are coralreefs that form around the lagoon (Sheppard et al., 2018). Some organisms associated with coral reefs e.g. Cyanobacteria, Sponge, Mikroalga, Mollusca, Echinodermata, Coelenterata, Arthropods and fish (Gani et al., 2017).

Coral reefs are experiencing serious threats stemming from human activity on land and in the oceans. Reported by (Brown, 1985; Jennings \& Polunin, 1996) coral reef damage for example

Copyright $($ C 2020, International Journal Papier Advance and Scientific Review, Under the license CC BY-SA 4.0

DOI: https://doi.org/10.47667/ijpasr.v2i1.93 
occurs; (1) on the coast of the south China Sea namely the utilization of corals for industry and the utilization of live corals for aquariums; (2) Damage to coral reefs in Indonesia occurs in several coastal locations of Madura, Thousand Islands, Maluku, Java. The sources of damage include sedimentation and pollution from the mainland, offshore oil exploitation, coral mining, tourism, unfriendly capture, bombing, and anchor fishing; (3) in the gulf of Thailand caused by chemical compounds (toxins) in sediment and suspended particles under the flow of water from the mainland and the use of trawl fishing and mining equipment for commercial activities; (4) in the Philippines coral reef damage occurs due to the use of cyanide in fishing, coral mining for industry and aquariums, and agriculture that is not environmentally friendly.

Some of the benefits of coral reefs for life are as follows; (1) Habitats for some organisms include phylum Mollusca, Coelenterata, Annelids, Arthropods and other types of fish; (2) Protection of the waves, especially for coastal areas so as to reduce the damage caused; (3) Places of foraging and spawning and nurturing of several types of fish that have important economic value; (4) Functioning disaster mitigation of climate change through the absorption of carbon dioxide in the process of photosynthesis by zooxanthellae.

\section{Sources and Types of Pollution in Coastal Environments}

Pollution is the inclusion of substances, compounds or energy by humans directly or indirectly into the ocean waters covering the estuary area so as to threaten the life of the organism and disrupt the ecosystem and decrease the function of its designation (Islam, 2004). Materials, substances and chemical compounds that cause pollution are called pollutants. Pollution began to appear in line with the development of human civilization. For example the use of chemical compounds in agricultural intensification. Industrial liquid waste disposal, exploitation of mines, minerals, oil and waste from transportation combustion.

One of the areas that has a high level of vulnerability to pollution is the coast. Coastal ecosystems are the last dumping ground for all activities on land (Chen, 2002; Cotou, 2002; Dahuri et al., 2013; Dong, 2018; El Gammal et al., 2017; Kazour, 2019). High economic activity in coastal areas will put even higher pressures. Threats to coastal ecosystems include chemical compoundbased agriculture; (2) industrial waste disposal, domestic and hospitality waste, hospital waste entering the coastal water system; (3) transfortation discharge in the form of oil scattered in the water; (4) waste exploitation of offshore oil mines that pollute the environment; (5) the development of extractive coastal and marine tourism and triggering increased organic and plastic waste; (6) environmental degradation as a result of poverty by means of extractive utilization (Palunin, 1986; Wu et al., 2020).

The description above provides an explanation of the sources of pollution in coastal areas. Sources of pollution of coastal ecosystems based on their origin can be categorized into two main types, namely in situ and ex situ. Sources of ex situ pollution are outside the coastal ecosystem. For example, sources of pollution from land ecosystems and ocean ecosystems. Examples of contamination originating from terrestrial ecosystems are household waste, textile industry, suspended solids, food industry, and agricultural waste. While examples of pollution that comes from the ocean is waste oil or hydrocarbons. Land waste enters the coastal waters ecosystem carried by river water flow. Meanwhile, marine waste enters the coast carried by tides, currents and waves and wind. The type of in situ waste is waste that comes from within the coastal 
ecosystem itself. For example, oil spills at ports, organic waste from aquaculture and waste from marine tourism activities.

Pollution that occurs on the coast is generally anthropogenic. The pollution comes from economic and social activities that take place on land and at sea. According to (Peixoto et al., 2019; Wu et al., 2020) waste that enters the coast in various forms; (1) solid waste such as inorganic and organic waste; (2) liquid waste, such as chemical compounds originating from industrial, agricultural and offshore oil refineries; (3) sediments containing toxic chemical compounds carried by waterways from land; (4) heavy metals such as $\mathrm{Cu}, \mathrm{Cd}, \mathrm{Hg}$, and As very high contribute to the risk of cancer in adults and children; (5) residential and urban waste.

In the last decade, organic pollution has been reported to be increasing in number in coastal areas. One of the main stresses comes from excessive macronutrients (phosphate and nitrate) causing changes in trophic status leading to eutrophication (Meyer-Reil \& Koster, 2000). High levels of these nutrients can trigger high algae growth. Including the opportunity for algae blooms that have serious negative impacts on coastal organisms including humans. Because some types of algae are classified as Harmful Algae Bloom (HAB) such as Ceratium sp, Nitzschia sp, and Dinophysis (Choirun et al., 2015). Blooming micro algae will have an impact on decreasing the dissolved oxygen content in the waters. The implications will interfere with the aerobic decomposition of organic compounds and will interfere with the respiration of coastal fauna organisms including fish.

\section{Self-purification Capacity Related to Carrying Capacity}

Coastal areas are a unit of life systems that have distinctive ecosystem characteristics. Based on its natural nature, coastal ecosystems have the following main functions: (1) Providers of life support services because many contain natural resources that serve as energy sources including for humans; (2) Aesthetic service providers that can provide comfort so that many developed as tourist areas; (3) Natural resource providers that cannot be renewed. For example sand, minerals and oils that are very useful for development; (4) Environmental service providers such as deciphering waste dumped in coastal areas (Dahuri et al., 2013) .

Based on the four functions above, the function as a provider of waste-thinning environmental services becomes very important. The function of coastal ecosystems as decomposers will affect the existence of life support service providers and tourism service functions. Therefore, the development of coastal areas must require the functioning of self-purification capacity or assimilation to be maintained. The quality of coastal aquatic ecosystems is highly dependent onnatural self-purification (Otsuka et al., 2006). Coastal self-purification is the ability of coastal ecosystems to receive a certain amount of waste in complex natural processes and before there is any indication of a decrease in the function of its designation. according to (Ostroumov, 2004) interaction between physical, chemical and biological components is an important component in the self-purification process. Such interactions run very complex and dynamic in nature in the form of direct and indirect relationships.

Bengen (2002) stated that coastal and marine ecosystems have the ability to assimilate or selfpurify the waste that enters this ecosystem. Self-purification in coastal ecosystems occurs from the interaction of constituent components also occur due to physical dynamics such as tides, currents, waves and water flows from rivers. However, the ability of self-purification there is a limit if the incoming waste exceeds its carrying capacity then there will be, damage to coastal ecosystems. 
Dhinakaran \& Lipton (2014) explains some coastal organisms such as Holothuria sp produce bioactive. These chemical compounds are synthesized through secondary metabolism to protect themselves and self-purification in their environment. In addition, coastal ecosystems contain many microbes that are very important in the self-purification process. For example, the role of Pseudomonas and vibrio in the process of cellulose and chitin decomposition. While the bacteria Nitrosomonas, Nitrosocysteine, Nitrosospira, Nitrosolobus play a role in the conversion process from Ammonia $\left(\mathrm{NH}_{4}{ }^{+}\right)$to nitrite $\left(\mathrm{NO}_{2}^{-}\right)$. Further conversion from nitrite to nitrate $\left(\mathrm{NO}_{3}\right)$ by baktérie Nitrobacter, Nitrosococcus, Nitrospina. The nitrification process tends to lower the $\mathrm{pH}$ and denitrification tends to increase the $\mathrm{pH}$, so the $\mathrm{pH}$ of the waters becomes neutral (Toorn, 1987).

Chao et al., (2015) stated one of the services and benefits of coastal areas is the ability to selfpurification naturally. Some factors that control self-purification on the coast include (1) morphological and hydrological factors; (2) physical and chemical processes such as sedimentation, accumulation, nutrient load; (3) biological aspects include food networks, dominance of macrophyta or microalgae, decrease in biodiversity and tropic status (Schiewer \& Schernewski, 2004). Coastal vegetation is also considered to have an important function in conducting the self-purification process. For example, mangrove forest vegetation and seagrass fields are exosposeses rich in organic and inorganic materials. The availability of organic and inorganic materials as a source of nutrients for bacteria or other microorganisms in conducting metabolism that produces bioactive functioning in self-purification can certainly improve the ability of self-purification of coastal ecosisitem. On the other hand, mangrove vegetation as a sediment trap can increase water transparency so that the photosynthesis process is optimal. This will have an impact on the process of reoxygenesis that goes well.

The description of the self-purification mechanism explains that self-purification is a process that occurs in every natural ecosystem through two main functions, namely energy flow and material flow. This is supported by the physical-chemical factors of coastal environments play a role in the self-purification process. The dynamic of coastal waters in the form of waves, currents and tides causes self-purification to run effectively. However, not all coastal environments have the same self-purification capabilities due to different environmental conditions, such as the existence of mangrove, seagrass and coral reef ecosystems and their types of coastal ecosystems. A coast that has a complete ecosystem is different from a coast that does not have a complete ecosystem related to self-purification capabilities.

Seguchi et al., (2002) states there are three coastal functions namely primary producer, tourism and natural purification. Self-purification occurs through biological activity by living organisms by absorbing or decomposing chemical compounds in the waters. For example, the process of denitrification and nitrification by bacteria. Ostroumov (2004); (Schiewer \& Schernewski, 2004) explaining the self-purification mechanism in general consists of three aspects, namely: (1) Filtration or absorption activities by organisms, e.g. all invertebrates that have a habit of filtering, macrophytes that can capture biogenic and pollutants that enter the ecosystem, and microorganisms that absorb heavy metals; (2) Mechanism of transformation of chemical compounds between ecological compartments, such as from water to sediment, from water to atmosphere, from coastal waters to land through tidal movements, transfer from water to land through feeding net mechanisms (fish eaten by birds); (3) Pollutant degradation, including cellular enzymatic processes, extracellular enzymatic processes present in water and free radical processes 
involving biological agents of origin. Thus, self-purification capability is influenced by several factors, namely (1) the type of waste that enters, (2) the amount of waste that enters, (3) and the activity of organisms, (4) and the physical-chemical conditions of coastal waters. For example, salinity, dissolved oxygen content and incoming nutrients.

On the other hand, the characteristics of the beach also affect the self-purification process. Bengen (2002) stated that sandy beaches have a low level of primary productivity, while rocky beaches that have a higher level of water clarity and a high dissolved oxygen content will certainly have a direct impact on the high primary productivity. Naturally the interaction between chemical and biological physics processes will have an impact on the self-purification process. Coastal selfpurification capabilities depend heavily on environmental support. The carrying capacity of coastal ecosystems will be optimal if the ecosystem is in balance and vice versa if the carrying capacity of coastal ecosystems is not balanced then the ability of self-purification will naturally also be disrupted.

Support capacity is the ability of an ecosystem in supporting the life of a population. Thus, the optimal population number is one that can be supported by its natural resources. Conversely, if the population cannot be supported then the carrying capacity has been exceeded (Inglis et al., 2000). Menurut (Lankford et al., 2005) conception of carrying capacity can be classified into four types, namely economic, physical, social and ecological aspects. Ecological support capacity is the ability of natural resources to provide ecological services to the organisms that live in them. For example, the life of fish or other living organisms in coastal ecosystems. Coastal ecosystems are said to be disrupted when, the life of organisms in those ecosystems begin to be ecologically depressed. A good natural indicator to see the carrying capacity of ecosystems is living organisms. There are three factors that affect the ecosystem's carrying capacity, namely (1) the number of resources available and can be utilized in the ecosystem; (2) the size of the population in the ecosystem; (3) the amount of consumption of each individual in the population in the ecosystem. If it is associated between self-purification and environmental support, it can be concluded that the self-purification capability of an ecosystem is highly determined by the carrying capacity of the environment. Because self-purification is not merely a physical-chemical process of the coastal environment but its interaction with biological components. Therefore, in order for the self-purification function in coastal ecosystems to continue, the management of natural resources must pay attention to the dimension of ecological sustainability.

\section{Conclusion}

Natural self-purification is a natural event in every natural ecosystem including the coast. Selfpurification is highly dependent on the biological activity of organisms present in coastal ecosystems and the dynamics of physical-chemical factors. Self-purification in the process includes three things, namely; filtration or absorption by organisms, transformation of chemical compounds between ecological compartments and decomposition of pollutants and other chemical compounds. The role of mangrove, coral and seagrass ecosystems is very important in the process of self-purification on the coast. Because the position of the ecosystem serves as a habitat for organisms that play an important role in the process of self-purification. Therefore, each coastal environment will have different self-purification capabilities, depending on the constituents of the ecosystem. In addition, self-purification and the carrying capacity of coastal areas are two aspects of interdependence. Effective self-purification will keep the ecosystem's carrying capacity running optimally. Because self-purification is part of the functional process of ecosystems in the form of

Copyright (C) 2020, International Journal Papier Advance and Scientific Review, Under the license CC BY-SA 4.0 
material cycles and energy flows, the preservation of the ecological functions of coastal ecosystems including coral reefs, seagrasses and mangroves is very important to streamline its self-purification capabilities.

\section{References}

Allgeier, J. E., Layman, C. A., Montaña, C. G., Hensel, E., Appaldo, R., \& Rosemond, A. D. (2018). Anthropogenic versus fish-derived nutrient effects on seagrass community structure and function. Ecology, 99(8), 1792-1801. https://doi.org/10.1002/ecy.2388

Beatly, T., Brower, D. ., \& Schwab, A. . (2002). An introduction to coastal zone management. In ISLAND PRESS. https://doi.org/10.1016/s0964-5691(96)00034-8

Bengen, D. G. (2002). Sinopsis Ekosistem dan Sumberdaya Alam Pesisir dan Laut serta Prinsip Pengelolaannya. In Pusat Kajian Sumberdaya dan Laut, IPB. Bogor.

Boaden, J. S. P. (1996). An Introduction to Coastal Ecology. Blackie Academic \& Professional, an Imprint of Chapman \& Hall, 2-6 Boundary Row, London SE1 8HN, UK. https://doi.org/10.1007/978-94-011-7100-7

Brown, B. E. (1985). Human Induced Damage to Coral Reefs. 13(13), 1529-1532.

Choirun, A., Sari, S. H. J., \& Iranawati, F. (2015). Identifikasi Fitoplankton Spesies Harmfull Algae Bloom (Hab) Saat Kondisi Pasang Di Perairan Pesisir Brondong, Lamongan, Jawa Timur. Torani (Jurnal Ilmu Kelautan Dan Perikanan), 25(2), 58-66.

Dahuri, R., Rais, J., Ginting, S. ., \& Sitepu, M. . (2001). Pengelolaan sumberdaya wilayah pesisir dan lautan secara terpadu. In PT. Pradnya Paramita. Jakarta.

Dhinakaran, D. I., \& Lipton, A. P. (2014). Bioactive compounds from Holothuria atra of Indian ocean. SpringerPlus, 3(1). https://doi.org/10.1186/2193-1801-3-673

French, P. W. (2004). The changing nature of, and approaches to, UK coastal management at the start of the twenty-first century. Geographical Journal, 170(2), 116-125. https://doi.org/10.1111/j.0016-7398.2004.00113.x

Gani, A., Rosyida, E., \& Serdiati, N. (2017). Keanekaragaman jenis invertebrata yang berasosiasi dengan ekosistem terumbu karang di perairan teluk palu kelurahan panau kota palu. Jurnal Agrisains, 18(April), 38-45.

Huang, J., Cui, S., Qiu, Q., Shi, L., \& Ma, K. (2010). Estimates of exposure of a coastal city to spatial use changes - A case study in Xiamen. International Journal of Sustainable Development and World Ecology, 17(4), 292-298. https://doi.org/10.1080/13504509.2010.488413

Hutomo, M., \& Azkab,M, H. (1987). ) dan M.H. Azkab 2 ). Peranan Lamun Di Lingkungan Laut Dangkal, XII(1), 13-23.

Inglis, G. J., Hayden, B. J., \& Ross, A. H. (2000). An overview of factors affecting the carrying capacity of coastal embayments for mussel culture. NIWA Client Report: CHC00/69 $\begin{array}{llll}\text { Project No. MFE00505, August, } & 38 .\end{array}$ http://www.aqua.stir.ac.uk/public/GISAP/pdfs/NIWA.pdf 
Islam, M. S. (2004). Impacts of pollution on coastal and marine ecosystems including coastal and marine fisheries and approach for management: A review and synthesis. In Marine Pollution Bulletin (Vol. 48, Issue 7, pp. 624-649). https://doi.org/10.1016/j.marpolbul.2003.12.004

Jennings, S., \& Polunin, N. V. C. (1996). Impacts of fishing on tropical reef ecosystems. Ambio, 25(1), 44-49. https://doi.org/10.2307/4314417

Kawaroe, M., Bengen, D. G., Eidman, M., \& Boer, M. (2001). Kontribusi Ekosistem Mangrove Terhadap Struktur Komunitas Ikan di Pantai Utara Kabupaten Subang, Jawa Barat. Pesisr Dan Lautan, 3(3), 12-25.

Kohata, K., Hiwatari, T., \& Hagiwara, T. (2003). Natural water-purification system observed in a shallow coastal lagoon: Matsukawa-ura, Japan. Marine Pollution Bulletin, 47(1-6), 148154. https://doi.org/10.1016/S0025-326X(03)00055-9

Lacerda, L. D. (2002). Mangrove ecosystems function and management. In L. Lacarde (Ed.), Springer-Verlag Berlin Heidelberg New York in 2002 (Issue 1, p. 307 pages). SpringerVerlag Berlin Heidelberg New York. https://doi.org/10.1007/978-3-662-04713-2

Lankford, S. V, Inui, Y., Whittle, A., Luna, R., \& Tyrone, D. (2005). Sustainability of coastal/marine recreation: Modeling social carrying capacity for Hanauma Bay, Hawaii. March, 114.http://files/15078/Lankford_et_al_2005_NOAASeagrant.PDF

Larkum, W. . A., Orth, J. R., \& Duarte, C. M. (2006). Seagrasses: Biology, Ecology and Conservation. Published by Springer, P.O. Box 17, 3300 AA Dordrecht, The Netherlands. https://doi.org/10.1007/1-4020-2983-7

Li, C., Xu, C., He, L., T, W. S., Chen, Y. H., \& Xu, H. (2015). Purification function of coastalterrestrial ecosystems and its evaluation: A case study of Huanghua City. Journal of Ecology and Rural Environment, 31(4), 1673-4831. https://doi.org/10.11934/j.issn.16734831.2015.04.010

Liu, S. L., Jiang, Z. J., Wu, Y. C., Zhang, J. P., \& Huang, X. P. (2015). Nursery function of seagrass beds and its mechanisms. Shengtai Xuebao/ Acta Ecologica Sinica, 35(24). https://doi.org/10.5846/stxh201406181269

Martosubroto, P., \& Naamin, N. (1977). Relationship Between Tidal Forests (Mangroves) and Commercial Shrimp Production in Indonesia. Marine Research in Indonesia, 18(18), 8186. https://doi.org/10.14203/mri.v18i0.363

Meyer-Reil, L. A., \& Koster, M. (2000). Eutrophication of marine waters: Effects on benthic microbial communities. Marine Pollution Bulletin, 41(1-6), 257-265.

Moberg, F., \& Folke, C. (1999). Ecological goods and services of coral reef ecosystems. Ecological Economics, 29(2), 215-233. https://doi.org/10.1016/S0921-8009(99)00009-9

Nagelkerken, I., Kleijnen, S., Klop, T., Van Den Brand, R. A. C. J., Cocheret De La Morinière, E., \& Van Der Velde, G. (2001). Dependence of Caribbean reef fishes on mangroves and seagrass beds as nursery habitats: A comparison of fish faunas between bays with and without mangroves/seagrass beds. Marine Ecology Progress Series. https://doi.org/10.3354/meps 214225 
Odum, H. T., \& Odum, E. P. (1955). Trophic Structure and Productivity of a Windward Coral Reef Community on Eniwetok Atoll Author ( s ): Howard T . Odum and Eugene P . Odum Published by: Ecological Society of America Stable URL: http://www.jstor.org/stable/1943285 . Your use of the JSTOR. Ecological Monograph, 25(3), 291-320.

Ostroumov, S. A. (2004). On the biotic self-purification of aquatic ecosystems: elements of the theory. Doklady Biological Sciences: Proceedings of the Academy of Sciences of the USSR, Biological Sciences Sections / Translated from Russian, 396(1), 206-211. https://doi.org/10.1023/B:DOBS.0000033278.12858.12

Otsuka, K., Nakatani, N., \& Yao, M. (2006). Estimation of water purification efficiency of plural environmental restoration technologies for enclosed coastal seas. Proceedings of the International Offshore and Polar Engineering Conference, 4, 556-564.

Palunin, N. (1986). Ecosystem Theory and Application. John Wiley \& Sons.

Peixoto, D., Pinheiro, C., Amorim, J., Oliva-Teles, L., Guilhermino, L., \& Vieira, M. N. (2019). Microplastic pollution in commercial salt for human consumption: A review. Estuarine, Coastal and Shelf Science, 219(January), 161-168. https://doi.org/10.1016/j.ecss.2019.02.018

Polidoro, B. A., Carpenter, K. E., Collins, L., Duke, N. C., Ellison, A. M., Ellison, J. C., Farnsworth, E. J., Fernando, E. S., Kathiresan, K., Koedam, N. E., Livingstone, S. R., Miyagi, T., Moore, G. E., Nam, V. N., Ong, J. E., Primavera, J. H., Salmo, S. G., Sanciangco, J. C., Sukardjo, S., Yong, J. W. H. (2010). The loss of species: Mangrove extinction risk and geographic areas of global concern. PLoS ONE, 5(4). https://doi.org/10.1371/journal.pone.0010095

Quisthoudt, K., Schmitz, N., Randin, C. F., Dahdouh-Guebas, F., Robert, E. M. R., \& Koedam, N. (2012). Temperature variation among mangrove latitudinal range limits worldwide. Trees - Structure and Function, 26(6), 1919-1931. https://doi.org/10.1007/s00468-012-0760-1

Randall, J. (1965). Grazing Effect on Sea Grasses by Herbivorous Reef Fishes in the West Indies Author ( s ): John E . Randall Published by : Ecological Society of America Stable URL : http://www.jstor.org/stable/1936328 . America, 46(3), 255-260.

Schiewer, U., \& Schernewski, G. (2004). Self-purification capacity and management of Baltic coastal ecosystems. Journal of Coastal Conservation, 10(1-2), 25-32. https://doi.org/10.1652/1400-0350(2004)010[0025:SCAMOB]2.0.CO;2

Seguchi, M., Koriyama, M., \& Deguchi, O. (2002). Effects of Temperature and Nitrate Concentration on Denitrification Capacity of Coastal Mud in the Ariake Sea. Bull. Fac. Agr., Saga Univ. N, 87, 79-86.

Sheppard, C. H. R. S., Davy, S. K., Pilling, G. M., \& Graham, N. A. J. (2018). The Biology of Coral Reefs. In Oxford University Press (Second). OXFORD UNIVERSITY PRESS. https://doi.org/10.1093/oso/9780198787341.001.0001

Supriharyono. (2000). Pelestarian dan Pengelolaan Sumber Daya Alam di Wilayah Pesisir Tropis. Gramedia Pustaka Utama. 
Toorn, J. D. V. (1987). A Biological Approach to Dolphinarium Water Purification: I. Theoretical Aspek. Aquatic Mammals, 13(3), 83-92.

Turner, R. K., Lorenzoni, I., Beaumont, N., Bateman, I. J., Langford, I. H., \& McDonald, A. L. (1998). Coastal management and environmental economics: analysing environmental and socio-economic changes on the UK coast. Working Paper - Centre for Social and Economic Research on the Global Environment, 164(3), 269-281.

Twilley, R. R., Chen, R. H., \& Hargis, T. (1992). Carbon sinks in mangroves and their implications to carbon budget of tropical coastal ecosystems. Water, Air, \& Soil Pollution, 64(1-2), 265-288. https://doi.org/10.1007/BF00477106

Wu, J., Lu, J., Zhang, C., Zhang, Y., Lin, Y., \& Xu, J. (2020). Pollution, sources, and risks of heavy metals in coastal waters of China. Human and Ecological Risk Assessment, 26(8), 2011-2026. https://doi.org/10.1080/10807039.2019.1634466 